\title{
Treatment of post-traumatic deformities
}

\author{
Ranjit Singh Gill \\ From 10th Congress of the Asia-Pacific Federation of Societies of Surgery fo the Hand and the 6th Congress \\ of Asia-Pacific Federation of Societies of Hand Therapists \\ Kuala Lumpur, Malaysia. 2-4 October 2014
}

Surgeons are experts at making the most of conventional 2D image data to prepare for their complex procedures. However, even the best planners can struggle with limited information that is available in $2 \mathrm{D}$ images and with the inability to try out multiple approaches before entering the OR. Surgeons using 2D images to diagnose and treat complex reconstructive bone procedures know how frustrating it can be to wait until the first incision is made to get the full picture of the patient's pathology.

Fortunately, 3D virtual surgical planning is now available to remove many of the hurdles involved in determining the best plan and transferring it to reality.

This presentation outlines the use of 3D virtual surgical planning and the development of patient specific guides to improve the surgical accuracy and outcomes of corrective surgery for malunion deformity of the forearm. This technology involves the use of CT Scan imaging and turning the patient's CT data into virtual surgical plans, patient-specific cut and drill guides, and physical models of the patient's anatomy. The latter part of the technology involves the use of $3 \mathrm{D}$ printing to develop the patient's physical bone models, cut and drill guides.

Published: 19 May 2015

doi:10.1186/1753-6561-9-S3-A95

Cite this article as: Gill: Treatment of post-traumatic deformities. BMC

Proceedings 2015 9(Suppl 3):A95.

Kuala Lumpur Sports Medical Center, Kuala Lumpur, 50490, Malaysia

Submit your next manuscript to BioMed Central and take full advantage of:

- Convenient online submission

- Thorough peer review

- No space constraints or color figure charges

- Immediate publication on acceptance

- Inclusion in PubMed, CAS, Scopus and Google Scholar

- Research which is freely available for redistribution 